KOVALEM

\title{
POTENSI ANTIOKSIDAN METABOLIT SEKUNDER FRAKSI ETIL ASETAT DARI KULIT BATANG EBONI (Diospyros celebica Bakh.)
}

\section{[Antioxidant Potential of The Secondary Metabolite Compund Ethyl Acetate From Ebony Bark (Diospyros celebica Bakh.)]}

\author{
Vivi Sasmita ${ }^{1^{\star}}$, Ahmad Ridhay ${ }^{1}$, Hardi Ys $^{1}$ \\ 1) Jurusan Kimia, Fakultas MIPA, Universitas Tadulako, Palu \\ Jl. Soekarno Hatta Km.9, Kampus Bumi Tadulako Tondo Palu, Telp. 0451- 422611
}

*)Coresponding author: sasmitathomes@gmail.com (085145045652)

Diterima 26 Desember 2018, Disetujui 2 Juni 2019

\begin{abstract}
Research on the antioxidant potential of the secondary metabolite compound, ethyl acetate from ebony bark (Diospyros celebica Bakh.) has been conducted. This study aims to characterize and determine the antioxidant activity of secondary metabolites of ethyl acetate fraction from ebony bark. Ethyl acetate extract was fractionated using Liquid Vacum Chromatography (KVC) and Gravity Column Chromatography (KKG). The isolated compounds were characterized using UV-Vis and IR spectrophotometers. Data on maximum absorption of $\lambda_{\max } 273 \mathrm{~nm}$ from UV-Vis analysis showed the presence of chromophore phenol. IR spectral data showed several specific peaks, among others, at wave number $(\mathrm{v})$ of $3425.58 \mathrm{~cm}^{-1}$ indicating the presence of $-\mathrm{OH}$ group, $\mathrm{C}-\mathrm{H}$ aliphatic bond at $\mathrm{v}$ of $2924.09 \mathrm{~cm}^{-1}$ and $2854.65 \mathrm{~cm}^{-1}$, and the peak at $\mathrm{v}$ of $1604.77-1465.90 \mathrm{~cm}^{-1}$ and $3078.39 \mathrm{~cm}^{-1}$ indicated the aromatic group, reinforcing the assumption that the isolates produced were phenolic compounds. $\mathrm{IC}_{50}$ value of $75.47 \mu \mathrm{g} / \mathrm{mL}$ from antioxidant activity testing showed that the isolates obtained were antioxidant compounds with strong antioxidant categories.
\end{abstract}

Keyword : antioxidant, Diospyros, ebony, phenolic, isolation

\begin{abstract}
ABSTRAK
Telah dilakukan penelitian terhadap potensi antioksidan senyawa metabolit sekunder fraksi etil asetat dari kulit batang eboni (Diospyros celebica Bakh.). Penelitian ini bertujuan untuk mengkarakterisasi serta mengetahui aktivitas antioksidan senyawa metabolit sekunder fraksi etil asetat dari kulit batang eboni. Ekstrak etil asetat difraksinasi menggunakan Kromatografi Vakum Cair (KVC) dan Kromatografi Kolom Gravitasi (KKG). Senyawa hasil isolasi dikarakterisasi menggunakan spektrofotometer UV-Vis dan IR. Data pada serapan maksimum $\lambda_{\text {maks }} 273 \mathrm{~nm}$ dari analisis UV-Vis menunjukkan adanya kromofor fenol. Data spektra IR memperlihatkan beberapa puncak spesifik antara lain pada bilangan gelombang (v) $3425,58 \mathrm{~cm}^{-1}$ mengindikasikan adanya gugus $-\mathrm{OH}$, ikatan $\mathrm{C}-\mathrm{H}$ alifatik pada $\mathrm{u} 2924,09$ dan 2854,65 $\mathrm{cm}^{-1}$, serta adanya puncak pada $\mathrm{v} 1604,77-1465,90 \mathrm{~cm}^{-1}$ dan $3078,39 \mathrm{~cm}^{-1}$ mengindikasikan gugus aromatik, memperkuat dugaan bahwa isolat yang dihasilkan adalah senyawa fenolik. Nilai $\mathrm{IC}_{50}$ sebesar $75,47 \mu \mathrm{g} / \mathrm{mL}$ dari pengujian aktivitas antioksidan menunjukkan bahwa isolat yang diperoleh adalah senyawa antioksidan dengan kategori antioksidan kuat.
\end{abstract}

Kata Kunci : antioksidan, Diospyros, eboni, fenolik, isolasi 


\section{LATAR BELAKANG}

Radikal bebas merupakan senyawa yang memiliki sifat kereaktifan yang sangat tinggi, karena adanya elektron yang tidak berpasangan. Sifat tersebut mengakibatkan radikal bebas dapat mengambil elektron dari senyawa lain seperti protein, karbohidrat, lipid dan DNA untuk menetralkan diri (Sadeli, 2016). Hal ini dapat menyebabkan gangguan fungsi sel, kerusakan struktur sel, modifikasi molekul dan bahkan menyebabkan mutasi (Rahmawan dan Dwiatmaka, 2013). Jika Radikal bebas yang masuk ke dalam tubuh dalam jumlah yang berlebih dapat memicu terjadinya stres oksidatif sel, yang menyebabkan penyakit degeneratif seperti hipertensi, gejala penuaan, diabetes melitus, kanker dan kardiovaskuler (Praditasari, 2016).

Efek negatif dari radikal bebas dapat dieliminir dengan senyawa antioksidan, karena kemampuannya mengembalikan keseimbangan tubuh dan memperlambat oksidasi senyawa radikal bebas. Hal ini karena antioksidan mampu menstabilkan radikal bebas dengan mendonorkan atom hidrogen/elektron (Ikhlas, 2013).

Berdasarkan sumbernya, antioksidan dapat dibedakan menjadi antioksidan sintetis dan antioksidan alami. Namun, penggunaan antioksidan sintetis memiliki efek samping, karena dapat bersifat toksik dalam dosis yang tinggi, sehingga antioksidan alami perlu dikembangkan (Praditasari, 2016). Salah satu sumber antioksidan alami yang berasal dari tumbuhan adalah senyawa mtabolit sekunder golongan fenolik.

Senyawa fenolik memiliki kemampuan untuk menghambat autooksidasi melalui mekanisme radikal scavenging, yaitu dengan menyumbangkan satu elektron yang tidak berpasangan kepada radikal bebas (Pokorny et al., dalam Rahmawan dan Dwiatmaka, 2013).

Berdasarkan penelusuran literatur, genus Diospyros memiliki banyak kandungan fenolik dan beberapa diantaranya telah terbukti berpotensi sebagai antioksidan. Diospyros blancoi memiliki kandungan senyawa fenolik lebih dari $30 \mathrm{mg}$ ekivalen asam galat per gram ekstrak tanaman (Lee et al., dalam Rahmawan dan Dwiatmaka, 2013). Kandungan senyawa fenolik dalam $D$. blancoi memiliki aktivitas antioksidan yang tinggi (Khan et al., 2016). Kuersetin merupakan senyawa golongan flavonoid (fenolik) yang ditemukan pada $D$. virginiana L. (Duke dalam Rahmawan dan Dwiatmaka, 2013).

Huang et al., (2016) melaporkan daun kesemek (D. kaki) mengandung 2 jenis baru glukosida secoiridoid, yaitu persimmonoid A dan B dan beberapa senyawa lain seperti (+)-medioresinol, (+)pinoresinol, $(+)$-pinoresinol- $\beta$-D-glukosida dan (-)-(7'S,8S,8'R)-4,4'-dihidroksi3,3',5,5'-tetrametoksi-7',9-epoksilignan-9'ol-7-on. Ekstrak metanol buah sampanye (D. virginiana) menghasilkan beragam senyawa metabolit sekunder diantaranya 
m-gallat, asam gallat, luteolin, kuarsetin, mirisetin, mirisetin 3-O-ramnosid, miricetin 3-O-glukosida dan mirisetin 3-Oglukuronid (Rashet et al., 2014). Penelitian yang dilakukan Hermawan dan Dwiatmaka (2013), terhadap ekstrak apel beludru (Diospyros blancoi) membuktikan bahwa $D$. Blancoi berpotensi sebagai senyawa antioksidan dengan nilai $I_{50}$ sebesar $29,92 \mu \mathrm{g} / \mathrm{mL}$.

Eboni merupakan salah satu spesies dari genus Diospyros dengan nama ilmiah Diospyros celebica Bakh., yang secara alami hanya tumbuh di Sulawesi, terutama Sulawesi Tengah dan Sulawesi Selatan. Tumbuhan ini memiliki nilai ekonomis yang tinggi dan termasuk sumber devisa yang cukup besar (Pitopang et al. dalam Alwi et al., 2010). Namun demikian, belum banyak data ilmiah mengenai kandungan kimia yang terdapat dalam tumbuhan tersebut.

Uji fitokimia yang dilakukan Budiarso et al. (2016) terhadap ekstrak sabetan dan serutan kayu eboni menunjukkan bahwa tumbuhan ini mengandung senyawa alkaloid, flavonoid, tanin, saponin, steroid dan terpenoid. Beberapa senyawa metabolit sekunder diantaranya asam makasarat, Isocelabaquinon, 8-Metoksi-6metil-1,2-naptoquinon, diosindigo $B$ dan celebaquinon telah berhasil diisolasi dari tumbuhan eboni (Diospyros celebica) (Rauf et al., 2017). Beragam kandungan senyawa kimia pada tumbuhan selalu ditemukan pada tubuh tumbuhan seperti daun, biji, buah, akar, bunga, rimpang, atau kulit batang (Dorly, 2005).

Berdasarkan

pendekatan kemotaksonomi, tumbuhan-tumbuhan yang berasal dari genus yang sama cenderung memiliki kandungan dan struktur senyawa yang hampir sama, sehingga memungkinkan adanya aktivitas biologis yang sama (Tringali dalam Supriadi, 2018). Berdasarkan uraian di atas, maka perlu dilakukan penelitian lebih lanjut terhadap tumbuhan eboni, terutama untuk mengetahui potensi antioksidan senyawa metabolit sekunder yang terkandung dalam kulit batang tumbuhan ini.

\section{METODE PENELITIAN}

\section{Bahan dan Peralatan}

Sampel yang digunakan dalam penelitian ini adalah kulit batang eboni (Diospyros celebika Bakh.) yang diambil dari Desa Manimbaya kecamatan Balaesang Tanjung, Donggala dan desa Sausu Auma, kecamatan Sausu, Parigi Moutong. Adapun pelarut yang digunakan untuk ekstraksi dan kromatografi berkualitas teknis sedangkan untuk analisis spektroskopi berkualitas proanalisis (p.a). Bahan-bahan yang digunakan antara lain metanol, $n$-heksan, akuades, etil asetat, kloroform, aseton, kertas saring Whattman, larutan DPPH 50 $\mu \mathrm{M}$, asam askorbat, silika gel Merck 60 (70-200 mesh) untuk KKG, silika gel Merck $60 \mathrm{GF}_{254}$ (ukuran silika > 200 mesh) untuk impregnasi, silika gel Merck (35-70 
Mesh) untuk KVC dan plat KLT silika gel Merck kiesegal $60 \quad \mathrm{~F}_{254} \quad 0,25 \mathrm{~mm}$ untuk KLT.

Alat-alat yang digunakan meliputi rotary vacum evaporator, neraca analitik, 1 set alat kromatografi vakum cair (KVC), kromatografi kolom gravitasi, lampu UV, sendok zat, alu, botol kecil serta alat-alat gelas yang umun digunakan dalam penelitian kimia organik. Untuk analisis senyawa hasil isolasi digunakan instrumen UV-Vis dan IR.

\section{Prosedur Penelitian}

\section{Ekstraksi dan Isolasi}

Metode yang digunakan adalah hasil modifikasi metode Sari dan Taufiqurrohmah (2006). Sebanyak $2,5 \mathrm{Kg}$ kulit batang eboni (Diospyros celebca Bakh.) dimaserasi dengan pelarut metanol selama 3 kali 24 jam. Ekstrak hasil maserasi kemudian disaring dengan alat penyaring Buchner hingga didapatkan filtrat dan residu. Filtrat hasil penyaringan selanjutnya dipekatkan menggunakan rotary vacum evaporator dengan kecepatan $45 \mathrm{rpm}$ pada suhu $50^{\circ} \mathrm{C}$. Ekstrak metanol pekat dari sampel dipartisi berturut-turut dengan $n$-heksan dan etil asetat. Ekstrak etil asetat yang didapatkan diuapkan pelarutnya hingga kering dan ditimbang. Ekstrak tersebut difraksinasi menggunakan KVC, selanjutnya fraksi-fraksi yang diperoleh dikumpulkan berdasarkan hasil KLT dengan nilai $\mathrm{Rf}$ (Retention factor) yang relatif sama. Berdasarkan analisa $\mathrm{KLT}$, fraksi yang menunjukkan senyawa yang prospektif akan diisolasi untuk mendapatkan senyawa tunggal. Isolasi dan pemurnian senyawa dilakukan menggunakan teknik kromatografi vakum cair dan kromatografi kolom gravitasi.

Fraksi-fraksi yang akan difraksinasi maupun fraksi-fraksi setelah perlakuan fraksinasi semuanya diuji menggunakan KLT. Uji ini menggunakan sistem campuran eluen antara pelarut $n$-heksana, etil asetat, aseton, kloroform, dan metanol. Fraksi-fraksi tersebut dielusi pada plat $\mathrm{KLT}$, kemudian bercak yang diperoleh dilihat di bawah lampu UV untuk memperlihatkan bercak hasil KLT. Fraksifraksi yang menunjukkan Rf yang sama digabungkan dan dipekatkan kemudian difraksinasi lebih lanjut.

Ekstrak kasar selanjutnya difraksinasi menggunakan KVC. Sebanyak 3 kali berat sampel, silica gel sebagai fasa diam dimasukkan ke dalam kolom. Kolom dikemas kering dalam keadaan vakum. Eluen yang kepolarannya rendah dimasukkan terlebih dahulu, selanjutnya kolom divakum kembali hingga kering. Ekstrak etil asetat diimpregnasi, kemudian dimasukkan pada bagian atas kolom yang telah berisi fasa diam. Selanjutnya ekstrak/sampel dielusi menggunakan campuran pelarut heksanetil asetat secara gradient. Setiap penambahan eluen, kolom dihisap dengan vakum sampai kering. Fraksi yang diperoleh dikumpulkan dalam botol-botol kecil. 
Fraksi-fraksi hasil KVC difraksinasi lebih lanjut menggunakan kromatografi kolom gravitasi dengan adsorben silika gel Merck (35-70 Mesh). Slurry dari silika gel dimasukkan ke dalam kolom dan fasa diam diatur sedemikan sehingga rata dan tidak berongga. Kemudian sampel yang telah diimpregnasi dimasukkan ke dalam kolom tersebut. Agar proses elusi tidak terganggu, maka kolom diusahakan tidak kehabisan pelarut pada saat sampel dimasukkan.

\section{Identifikasi dan Karakterisasi Senyawa Metabolit Sekunder}

Senyawa yang diperoleh dianalisis menggunakan spektrofotometri yang bertujuan untuk mengidentifikasi adanya gugus kromofor seperti fenolik dan ikatan rangkap (UV) dan penentukan gugusgugus fungsi senyawa (IR).

\section{Pengujian Aktivitas Antioksidan}

Pengujian mengkuti metode Supriadi (2018). Sampel hasil isolasi dan asam askorbat (pembanding) dibuat larutan induk dengan konsentrasi 1000 $\mu \mathrm{g} / \mathrm{mL}$. isolasi dan asam askorbat masingmasing ditimbang sebanyak $3 \mathrm{mg}$ dan dilarutkan dengan $3 \mathrm{~mL}$ metanol p.a. Larutan induk sampel dan asam askorbat masing-masing diambil 2,25 mL, 19,44 $\mathrm{mL}, 17,85 \mathrm{~mL}, 15 \mathrm{~mL}$ dan $8,33 \mathrm{~mL}$ dimasukkan ke dalam labu ukur $25 \mathrm{~mL}$, kemudian dicukupkan volumenya dengan metanol p.a sampai tanda batas, untuk dibuatkan larutan uji seri konsentrasi 90 $\mu \mathrm{g} / \mathrm{ml}, 70 \mu \mathrm{g} / \mathrm{ml}, 50 \mu \mathrm{g} / \mathrm{ml}, 30 \mu \mathrm{g} / \mathrm{ml}$ dan
$10 \mu \mathrm{g} / \mathrm{ml}$. Larutan sampel dan pembanding masing-masing 0,2 $\mathrm{mL}$ dimasukkan ke dalam tabung reaksi dan ditambahkan 3,8 mL larutan DPPH $50 \mu \mathrm{M}$. Kemudian dikocok hingga homogen dan didiamkan selama 30 menit. Selanjutnya diukur serapannya (absorbansi) pada panjang gelombang $517 \mathrm{~nm}$. Kemudian dilakukan hingga 3 kali pengulangan. Aktivitas antioksidan diekspresikan sebagai persen inhibisi yang dapat ditentukan dengan menggunakan persamaan sebagai berikut:

$\%$ Inhibisi $=\frac{\text { Abs.blanko-Abs.Sampel }}{\text { Abs. blanko }} \times 100 \%$

Persen inhibisi dan konsentrasi sampel diplot masing-masing pada sumbu $x$ dan y dengan persamaan regresi linear. Sumbu y dari masing-masing sampel dinyatakan dengan nilai sebesar 50 dan sumbu x sebagai $I_{50}$ (Nurjanah dkk, 2011 dalam Ikhlas, 2013).

\section{HASIL DAN PEMBAHASAN}

\section{Hasil Ekstraksi dan Isolasi}

Sampel yang telah berbentuk serbuk diekstraksi menggunakan metode maserasi dengan pelarut metanol. Pada proses ini, membran dan dinding sel akan pecah, sehingga metabolit sekunder yang terkandung dalam kulit batang eboni akan tertarik oleh metanol.

Ekstrak metanol yang diperoleh dan telah dipekatkan dipartisi berturut-turut menggunakan pelarut $n$-heksan dan etil asetat yang ditambahkan air. Partisi menggunakan $n$-heksan dilakukan untuk 
memisahkan senyawa-senyawa non polar seperti triterpenoid, steroid, lemak dan pigmen yang masih terdapat dalam ekstrak metanol yang diperoleh. Sedangkan partisi menggunakan pelarut etil asetat bertujuan untuk menarik asam fenolat bebas dan aglikon flavonoid dari ekstrak. Adapun penambahan air saat partisi dengan etil asetat dilakukan karena metanol dan etil asetat sulit terpisah saat partisi.

Fraksi etil asetat $(120 \mathrm{~g})$ dielusi dengan pelarut $n$-heksan : etil asetat secara bergradien $(8: 2,7: 3,6: 4,5: 5,4: 6$, $3: 7,2: 8,9: 1$ dan $100 \%$ etil asetat). Dari hasil KVC diperoleh 17 subfraksi yang kemudian dibagi menjadi fraksi $A, B$ dan fraksi $\mathrm{C}$ berdasarkan perbedaan $\mathrm{Rf}$ dari masing-masing subfraksi. Hasil KVC dari sampel dapat dilihat pada kromatogram KLT (Gambar 1) yang menggunakan eluen $n$-heksan : etil asetat dengan perbandingan 5:5.

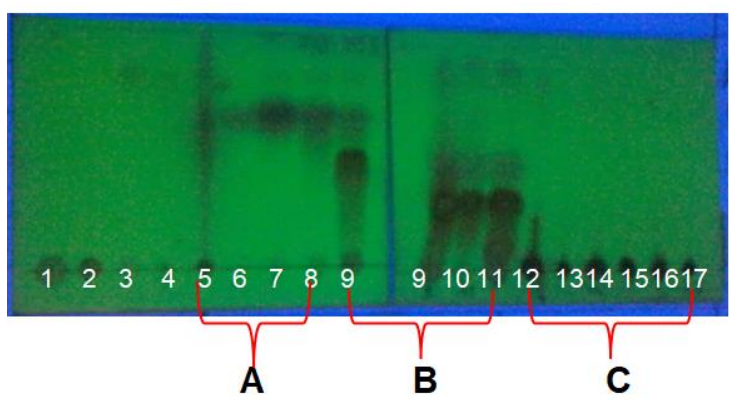

Gambar 1 Kromatogram KLT hasil KVC ekstrak etil asetat

Hasil KVC pada kromatogram KLT menunjukkan bahwa senyawa prospektif terdapat pada subfraksi A dan subfraksi B, sehingga memungkinkan untuk difraksinasi lebih lanjut. Terhadap subfraksi B (3,529 g) dilakukan fraksinasi/pemisahan menggunakan KKG dengan campuran eluen $n$-heksan : etil asetat secara bergradien $(9: 1,8: 2,7: 3$, $6: 4,5: 5,4: 6,3: 7,2: 8,1: 9$ dan $100 \%$ etil asetat). Hasil pemisahan dihasilkan subfraksi $B_{1}$ dan $B_{2}$ yang dapat dilihat pada kromatogram KLT dengan sistem campuran eluen $n$-heksan:etil asetat dengan perbandingan 6:4 (Gambar 2)

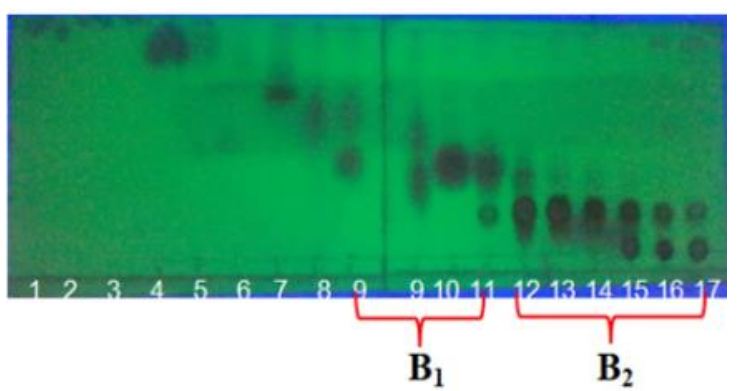

Gambar 2 Kromatogram KLT hasil KKG subfraksi B

Subfraksi $\mathrm{B}_{2}$ sejumlah $0,585 \mathrm{~g}$ lebih memungkinkan untuk difraksinasi lebih lanjut (Gambar 2). Menggunakan metode yang sama diperoleh subfraksi $B_{21}, B_{22}$ dan $\mathrm{B}_{23}$ (Gambar 3).
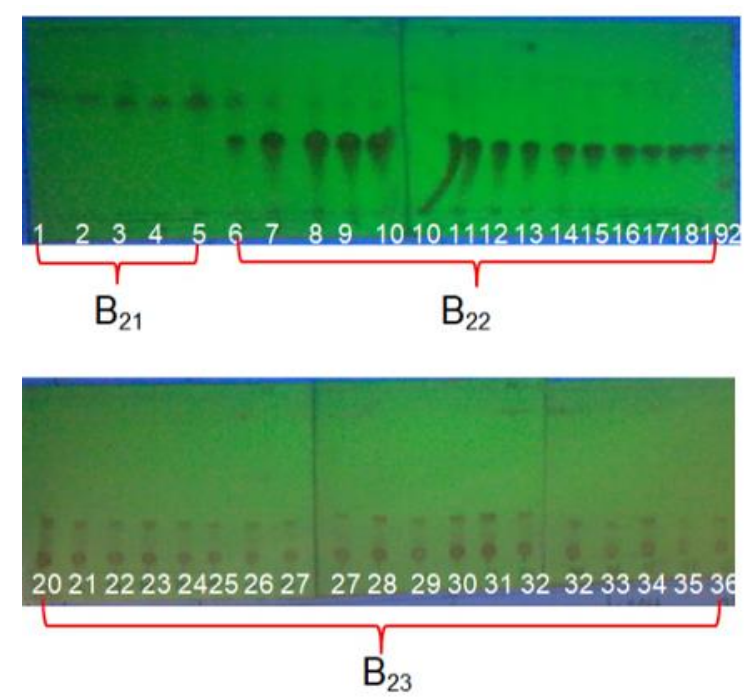

Gambar 3 Kromatogram KLT hasil KKG subfraksi $B_{2}$ 
Berdasarkan kromatogram KLT, dilakukan pemurnian pada subfraksi $B_{22}$ (31 $\mathrm{mg}$ ) dan diperoleh senyawa dengan spot tunggal (Gambar 4).

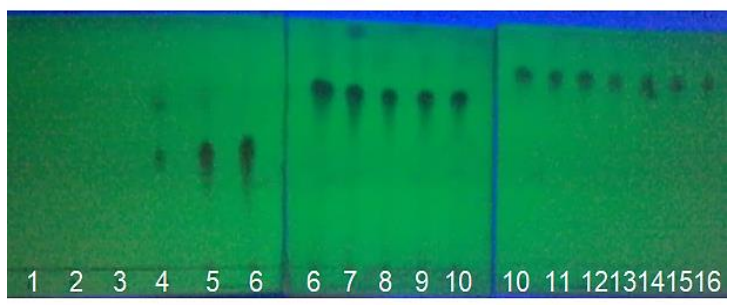

Gambar 4 Kromatogram KLT senyawa hasil isolasi

Untuk menyakinkan bahwa senyawa yang diperoleh benar-benar hanya terdiri dari 1 spot, maka dilakukan KLT dengan 3 sistem perbandingan eluen, yaitu kloroform : metanol (9:1), kloroform : etil asetat (8:2) dan kloroform : aseton $(9,4: 0,6)$. Hasil kromatogram KLT senyawa noda tunggal dengan 3 sistem perbandingan eluen diperlihatkan pada Gambar 5.
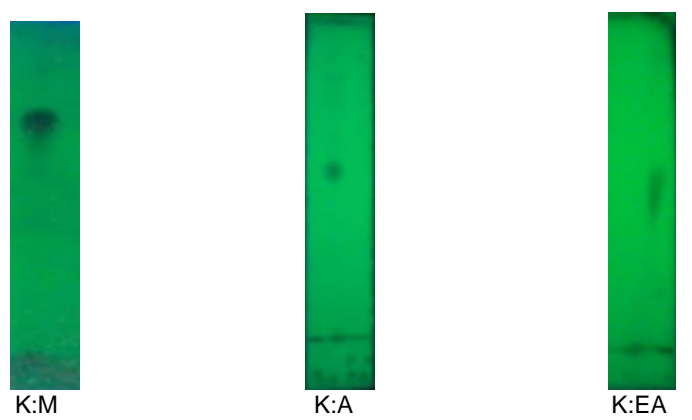

Gambar 5 Hasil kromatogram KLT spot noda tunggal dengan 3 sistem eluen campuran

Senyawa noda tunggal yang diperoleh dari hasil isolasi (isolat) adalah sebanyak $9 \mathrm{mg}$. Senyawa hasil isolasi tersebut diidentifikasi dengan menggunaan spektrofotometer UV-Vis untuk mengidentifikasi pola kromofor dan spektrofotometer

IR

untuk

mengidentifikasi gugus fungsi dari isolat yang diperoleh.

\section{Spektrum UV-Vis dan IR Senyawa Hasil Isolasi}

Spektrofotometer UV-Vis digunakan untuk analisis senyawa organik yang mengandung gugus kromoform yaitu diena terkinjugasi $(\mathrm{C}=\mathrm{C}-\mathrm{C}=\mathrm{C})$ dan enon $(\mathrm{C}=\mathrm{C}-\mathrm{C}=\mathrm{O})$, dengan kisaran sinar dengan panjang gelombang 200-400 nm. Panjang gelombang maksimum merupakan dasar dari analisis kualitatif karena setiap senyawa yang mengandung kromofor dan berwarna memiliki panjang gelombang maksimum yang spesifik (Ibrahim dan Marham, 2013).

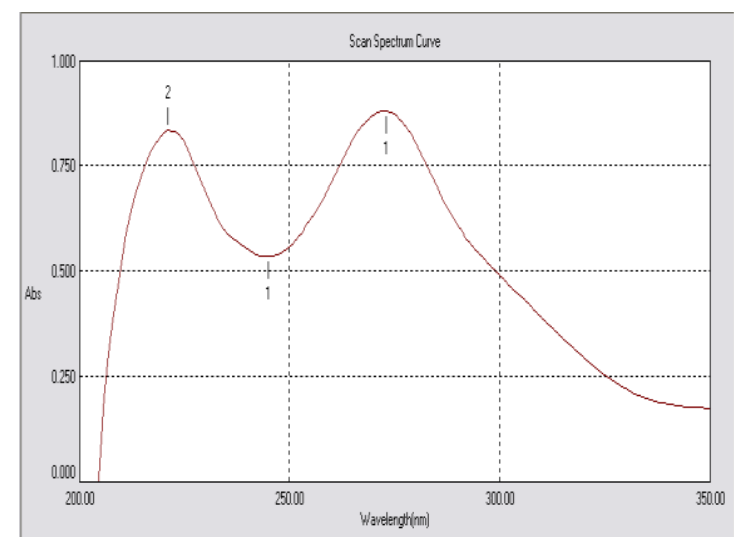

Gambar 6 Spektra UV-Vis Isolat Kulit Eboni

Hasil pegukuran dengan spektrofotometer UV-Vis, diperoleh 2 pita dengan $\lambda_{\text {maks }} 273 \mathrm{~nm}$ dan $221 \mathrm{~nm}$ yang menunjukkan adanya transisi dari $\pi \quad \pi^{*}$ dari ikatan rangkap $\mathrm{C}=\mathrm{C}$ (Gambar 6).

Adanya serapan pada panjang gelombang $273 \mathrm{~nm}$ menunjukkan senyawa hasil isolasi tersebut merupakan senyawa fenolik. Menurut Craswell (1991), 
senyawa fenolik akan menunjukkan serapan pada panjang gelombang kisaran 260-280 nm.

Setiap ikatan memiliki bilangan gelombang yang spesifik, menggunakan spekra IR dapat dilakukan pelacakan terhadap gugus fungsional suatu molekul (Sitorus, 2009). Spektrofotometer IR lebih banyak digunakan untuk melacak gugus fungsi yang berada pada kisaran 4000$1500 \mathrm{~cm}^{-1}$ (Ibrahim dan Marham, 2013).

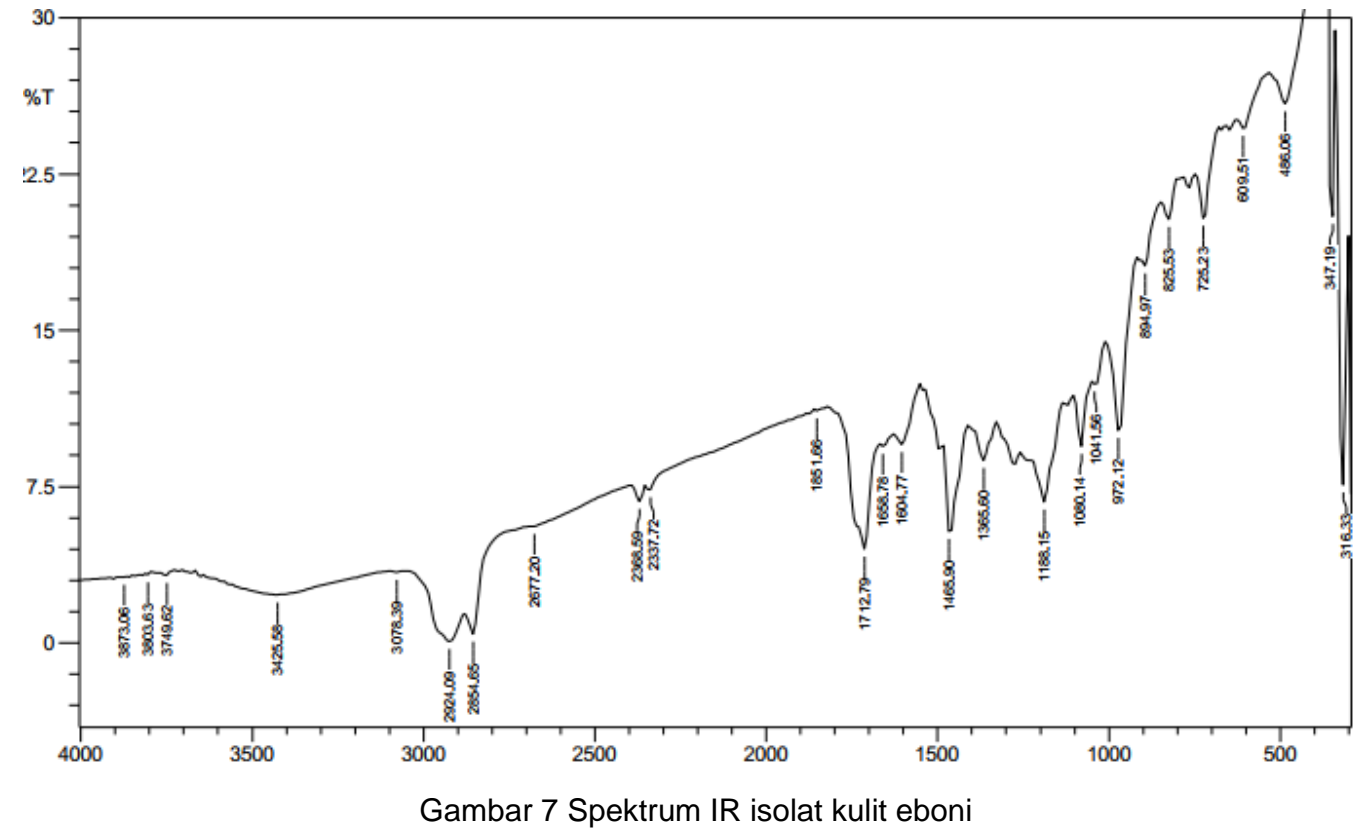

Spektra IR menunjukkan senyawa hasil isolasi memiliki beberapa gugus fungsi. Serapan pada 3425,58 $\mathrm{cm}^{-1}$ menunjukkan adanya gugus hidroksi $-\mathrm{OH}$ (Gambar 7). Menurut Sitorus (2009), alkohol dan fenol akan memunculkan serapan $(-\mathrm{OH})$ pada sekitar 3500-3300 $\mathrm{cm}^{-1}$. Serapan pada 2924,09-2854,65 $\mathrm{cm}^{-1}$ menunjukkcan adanya ikatan $\mathrm{C}-\mathrm{H}$ alifatik. Serapan pada $1604,77-1465,90 \mathrm{~cm}^{-1}$ dan serapan 3078,39 $\mathrm{cm}^{-1}$ menunjukkan adanya ikatan $\mathrm{C}=\mathrm{C}$ dan $=\mathrm{C}-\mathrm{H}$ dari senyawa aromatik.

Berdasarkan data spektra UV-Vis dan IR, isolat kulit eboni yang diperoleh diduga merupakan senyawa fenolik.
Aktivitas Antioksidan Senyawa Hasil Isolasi

Metode pengujian aktivitas antioksidan yang dipilih pada penelitian ini adalah metode DPPH. Metode ini merupakan metode yang sering digunakan dalam pengujian aktivitas antioksidan secara in vitro karena relatif murah dan sederhana dibandingkan metode in vitro lain.

Larutan DPPH bersifat radikal karena adanya elektron yang tidak berpasangan. Penambahan senyawa antioksidan akan menjadikan DPPH bersifat stabil karena donor proton sebagai pasangan elektron yang bersumber dari senyawa antioksidan dan akan menyebabkan penurunan 
absorbansi larutan DPPH secara stoikiometri.

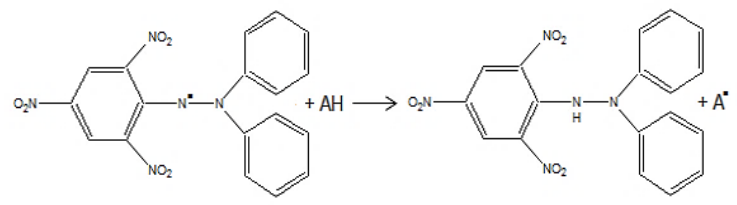

Gambar 8 Reaksi Radikal DDPH dengan antioksidan

Parameter pengujian aktivitas antioksidan dengan metode DPPH adalah nilai $I_{50}$ yaitu konsentrasi senyawa uji yang dibutuhkan untuk mengurangi radikal DPPH sebesar $50 \%$. Nilai $I_{50}$ diperoleh menggunakan persamaan regresi linear yang menunjukkan hubungan antara konsentrasi senyawa hasil isolasi dan persen aktivitas antioksidan (\% inhibisi). Semakin kecil nilai $I_{50}$ dari suatu senyawa, menunjukkan senyawa tersebut semakin potensial sebagai antioksidan
(Rahmawan dan Dwiatmaka, 2013). Menurut Hidajat (2005), senyawa yang memiliki nilai $\mathrm{IC}_{50}<50 \mu \mathrm{g} / \mathrm{mL}$ tergolong aktivitas antioksidan sangat kuat, antioksidan kuat jika memiliki nilai $\mathrm{IC}_{50} 50$ $100 \mu \mathrm{g} / \mathrm{mL}$, antioksidan sedang jika memiliki nilai $I_{50} \quad 100-150 \mu \mathrm{g} / \mathrm{mL}$, antioksidan lemah jika nilai $I_{50} \quad 150-200$ $\mu \mathrm{g} / \mathrm{mL}$ dan sangat lemah jika nilai $>200$ $\mu \mathrm{g} / \mathrm{mL}$.

Hasil pengukuran absorbansi menggunakan spektrofotometer UV-Vis menunjukkan bahwa isolat memiliki aktivitas antioksidan, hal ini ditandai dengan penurunan absorbansi DPPH setelah 30 menit penambahan larutan isolat. Dari data absorbansi yang diperoleh, ditentukan aktivitas penghambatan (\%inhibisi) radikal DPPH oleh senyawa hasil isolasi.

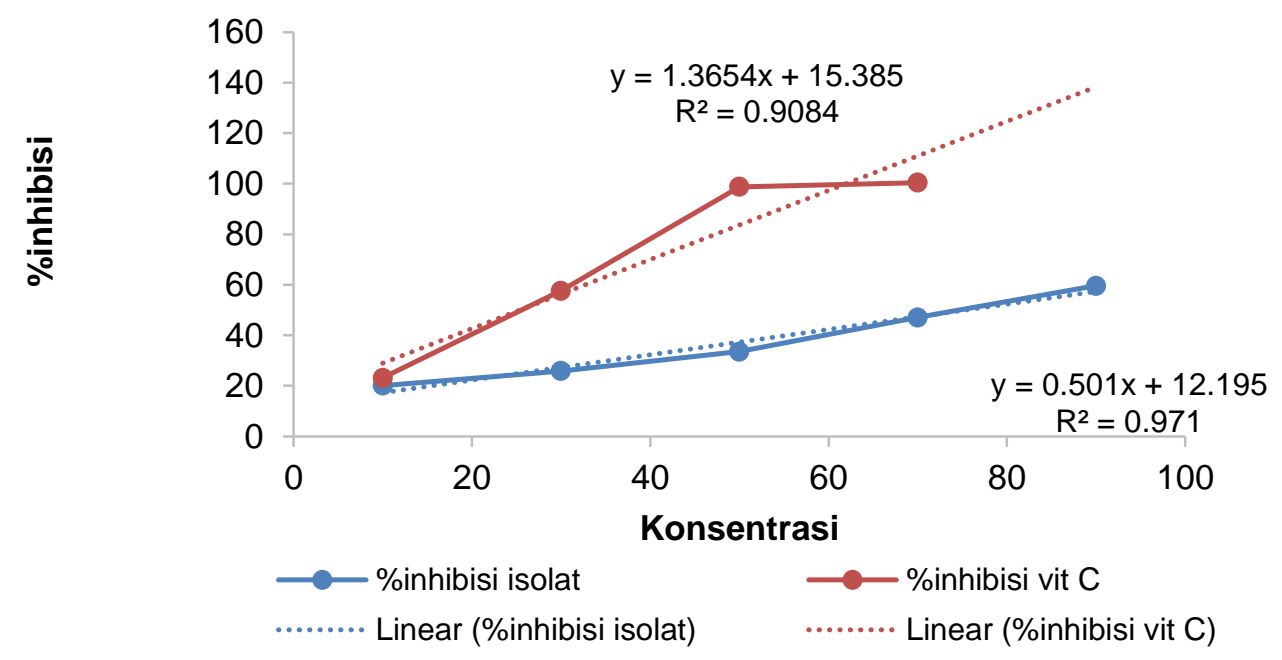

Gambar 9 Gafik regresi hubungan \%inhibisi dan konsentrasi

Senyawa hasil isolasi memiliki aktivitas antioksidan yang kuat dengan nilai $\mathrm{IC}_{50}$ sebesar $75,47 \mu \mathrm{g} / \mathrm{mL}$, walaupun tidak seperti aktivitas antioksidan dari vitamin $\mathrm{C}$ yang termasuk golongan antioksidan sangat kuat dengan nilai $\mathrm{IC}_{50}$ yang mencapai 23,62 $\mu \mathrm{g} / \mathrm{mL}$ (Gambar 9). 


\section{KESIMPULAN}

Senyawa metabolit sekunder yang berhasil diisolasi dari fraksi etil asetat kulit kayu eboni adalah senyawa fenolik dan berpotensi sebagai senyawa antioksidan dan tergolong antioksidan kuat dengan nilai $\mathrm{IC}_{50}$ sebesar $75,47 \mu \mathrm{g} / \mathrm{mL}$.

\section{DAFTAR PUSTAKA}

Alwi, M., Ramadanil, Dewa N.P. 2010. Ekstrak Serbuk Gergaji Kayu Eboni (Diospyros celebica Bakh.) sebagai Fungisida Terhadap Phytophthora palmivora Butler. Biocelebes, 4: 89-97.

Budiarso A E., Budi, A S., Kusuma I W. 2016. Analisis Fitokimia Ekstrak Kayu Eboni (Diospyros Celebica Bakh.). Warta Rimba, 4: 61-68.

Dorly. 2005. Potensi Tumbuhan Obat Indonesia DalamPengembangan Industri Agromedisin. Bogor: IPB.

Hidajat, B. 2005. Penggunaan Antioksidan Pada Anak. Surabaya: Fakultas Kedokteran Universitas Airlangga.

Huang, S. W., Jin-Wei Q., Xue S., Pin-Yi G., Ling-Zhi L., Qing-Bo L., Bei S., De-Ling W., and Shao-Jiang S. 2016. Secoiridoids and lignans from the leaves of Diospyros kaki Thunb.with antioxidant and neuroprotective activities. Journal of Functional Foods, 24: 183-195.

Ibrahim, S. Sitorus, M. 2013. Teknik Laboatorium Kimia Organik. Yogyakarta: Garaha IImu.

Ikhlas, N. 2013. Uji Aktivitas Antioksidan Ekstrak Herba Kemangi (Occinum americanum Linn) dengan Metode DPPH (2,2-difnil-1-pikrihidrazil). Skripsi. Jakarta: FKIK UIN Syarifhidayatullah.

Khan, M. A., Mahbubur R., Nazmul S., Saiful I. A., Badrul I., Jahangir A. K.,
Mamunur R., Golam S., and AHM Khurshid A. 2016. Comparative investigation of the free radical scavenging potential and anticancer, property of Diospyros blancoi (Ebenaceae). Asian Pacific Journal of Tropical Biomedicine, 6: 410-417.

Praditasari, A. 2016. Metode Uji Aktivitas Antioksidan Secara In Vitro Pada Ekstrak Tanaman: Review. Bandung: Fakultas Farmasi Universitas Padjajaran.

Rahmawan, J. B. Y. dan Y. Dwiatmaka. 2013. Penetapan kandungan fenolat Total dan Uji Aktivitas Antioksidan Menggunakn Radikal DPPH Fraksi Etil Asetat Sari Buah Apel Beludru (Diospyros blancaoi A. DC.). Jurnal Farmasi Sains dan Komunitas, 10: 101-110.

Rashet, K., Ana C, Jasmina G C, and Marina Si. 2014. Antibacterial and antifungal activities of methanol extract andphenolic compounds from Diospyros virginiana $\mathrm{L}$. Industrial Crops and Products,59: 210-215.

Rauf, A., Gias, U., Seema, P., Ajmal, K., Shobia, A. H., Saud, B., Khalid, A., Naveed, M., and Mohammad, S. M. 2017. Diospyros An Under-Utilized Multi-Purpose Plant : A review. Biomedicine and Pharmacotherapy, 91: 714-730.

Sadeli, R. A. 2016. Uji Aktivitas Antioksidan dengan Metode DPPH (1,1-diphenyl-2-pycryhydrazyl)

Ekstrak Bromelin Buah Nanas (Ananas comosus (L.) Merr). Skripsi. Yogyakarta: Fakultas Farmasi. Universitas Sanata Dharma.

Sari, O P., dan Taufiqurrohmah, T. 2006. Isolation and Identification of Flavonoid Compound Extractire Ethyl Acetate Fraction Extracted 
From The Rhizomes Fingerroot of (Boesenbergia pandurata (Roxb.) Schlecht) (Zingiberaceae). Indo. J. Chem., 6(2): 219 - 223.

Sitorus, M. 2009. Spektroskopi Elusidasi Struktur Molekul Organik. Yogyakarta : Graha IImu.
Supriadi, R. R. 2018. Potensi Antibakteri Senyawa Turunan Flavan-3-ol Dari Ekstrak Etil Asetat Kulit Batang Kemerakan Sapenit (Bauhinia Latisiliqua L). Skripsi. Fakultas Matematika dan IImu Pengetahuan Alam, Universitas Tadulako. Palu. 